\title{
The Pro and Counter Narratives of Anoole Memorial Monument in the Ethiopian Polity
}

\author{
Mulualem Daba Tola \\ Department of Public Relation and Communication Studies, College of Social Sciences and Humanities, Wolaita Sodo University, Wolaita \\ Sodo, Ethiopia
}

Email address:

mulualemdaba@yahoo.com

\section{To cite this article:}

Mulualem Daba Tola. The Pro and Counter Narratives of Anoole Memorial Monument in the Ethiopian Polity. Advances in Sciences and Humanities. Vol. 3, No. 5, 2017, pp. 43-49. doi: 10.11648/j.ash.20170305.11

Received: February 21, 2017; Accepted: March 8, 2017; Published: October 18, 2017

\begin{abstract}
Monuments play great role to transfer history from one generation to next generation. In Ethiopia, several memorial monuments have been constructed based on internal and external war histories. Historians usually wrote external war histories in which one country fought with another country or external power more or less in similar ways. On the histories of civil war, however, historians sometimes wrote either supporting or opposing, its good or bad side of the civil war. The narratives of civil war histories have been also reproduced by the victim and perpetrator side at different focal points. Accordingly, Anoole memorial monument was constructed based on civil war history happened during the monarchical regime in Ethiopia. The purpose of this study is to examine the Pro and Counter narratives of Anoole memorial monument in the Ethiopian polity. In-depth interview and document analysis are employed as means to generate data. The in-depth interview is held with professionals who have an opposite argument on the narratives of Anoole monument from academic arena (History, Political Science and Fine Art), and political sphere (Blue party, AEUP and OPDO). Three from Academics and three from political sphere in general six professionals are interviewed. Besides, four nongovernment magazines (Konjo, Addis Guday, Jano and Lomi) which gave high coverage for the issue of Anoole monument, and document of Oromia Culture and Tourism Bureau which take the initiation of Anoole memorial monument construction are selected for analysis. The collected data are analyzed qualitatively and the result of the study reveals that the main pro and counter narratives of Anoole memorial monument emphasize on its history that related to power and the design of Anoole statue. The study makes suggestions as to how these contradictory narratives about Anoole monument could be reconciled and the way statues based civil war histories as a commemorative text might be constructed in way that might reduce tensions among different groups.
\end{abstract}

Keywords: Anoole Statue, Civil War, History, Magazine

\section{Introduction}

Monuments have great values for the society. They are often constructed to represent the society's religion, culture, history and political aspects. They also function as gathering place of the society to strengthen cohesion. Predominantly, monuments have been used as site for political power legitimization. Statues erected across the globe have mainly political narratives. Stressing this, [1], Forest and Jonson (2001) also states that since $19^{\text {th }} \mathrm{C}$ statues have been used as weapons in political battle. Political actors have been contested for the political victory through constructing monuments that support their political ideology and altering, ignoring, or removing former monuments that have highly political connotations. Besides, different meaning and interpretations have been fixed to the same monument in different regimes, political leaders and interested groups have been engaged in the discourse of monuments symbolic dialog to define the historical figures and establish the historical incidents that frame state identities.

Among African countries, Ethiopia has long history of civilizations in terms of architectural art. [2], Since the Aksumite period (4th $\mathrm{C}-7$ th $\mathrm{C}$ ) different obelisk, edifices, and statues like the Axum obelisk ( $4^{\text {th }}$ C A. D) and Tiya monuments were curved for funeral or religious purposes. Others like largest edifice Ta'akha Maryam are also taken as one of Ethiopian ancient architectural civilization (Choudhury and Armstrong, 2006; Doresse, 1959; Finneran, 
et. al, 2012).

In the modern Ethiopian history (1855- present) several monuments which have historical narratives that related to power are constructed at different political juncture. In fact, the modern Ethiopia has passed through three political regimes: [3], Feudalism or imperial monarchy (1855-1928), Derg military junta regime which has socialist political ideology (1974-1991) and EPRDF (Ethiopian People Revolution Democratic Front) (1991-present) which advocate democracy (Bahru, 1991; Marcus, 1994; Merera, 2003; Turton et. al, 2006). In these three consecutive regimes, different monuments which have historical narratives that related to political power had been constructed.

Particularly in period of EPRDF, various memorial monuments are constructed at different regional cities of Ethiopia. The constructions of these monuments are tied with the introduction of federal system in the country. [4], As EPRDF officially come to power (1991), the federal system was introduced to decentralize power and resolve the nationalities question by accommodating the country's various ethno-linguistic groups. In fact, the system liberates different ethnic groups who were subjugated under the domination of one language, one culture and one religion. More than 80 ethnic group found in the country got the right of using their own vernacular language for learning, promoting their culture and preserving their own history. These rights also guaranteed by the 1995 constitution of Federal Democratic Republic of Ethiopia (FDRE) (Assefa, 2006; Hashim, 2010; Aalen, et.al, 2002). Statues constructed in this period mainly depend on the narratives of inter-political conflict between Derg, the socialist and EPRDF the multi party system to gain the political power. They are constructed for the commemoration of martyrs who died in this inter-political conflict. For instance, in Bahir Dar, city of Amhara regional state, Amhara people martyrs monument was constructed for the Amhara people's martyrs. Again, in Adama and Mekelle cities, martyrs' monuments were constructed for the people of Oromo and Tigray respectively.

Moreover, monuments that emblem the traumatic act happened during the imperial monarchy constructed in some parts of Oromia region. [5], In fact, during the reign of Emperor Menelik II (1885-1974) not only the Oromia parts like the Arsi, Bale, Harar but the southern parts such as Kaffa, Sidama and Wolaita people were also deteriorated due to they strongly resisted the imperial system. The emperor and his chiefs also made an atrocious act on these people in order to obey the system (Ezekiel, 2014; Haji Abbas, 1995, Mekuria, et.al, 1996). As a result, statues and museums are constructed at different parts of Oromia to commemorate what happened on these people during the imperial monarchy. Among of which, Anoole memorial monument was the one constructed at Arsii, Hexosa for the commemoration of Arsi Oromo people who suffered from atrocious act during the imperial monarchy. Therefore, this paper particularly examines the counter and pro narratives revolve on Anoole statue in the Ethiopian polity.

\section{An Overview of Anoole Memorial Monument}

Anoole memorial monument was constructed in Hetosa, Arsi zone, Oromia region, on April 6, 2014. It was erected as a tribute to the Arsi Oromo who were the victims of Emperor Menelik II's imperial expansion project carried out in the 1889. [6], Menelik II centralized his power in the northern and southern parts of Ethiopia through both peaceful and forceful subjugation. The forceful subjugation process was full of atrocities and loss of local people identity. The Arsi people particularly were the victim of the forceful subjugation due to they strongly resisted the expansion process. The army of Emperor Menelik II was defeated more than six times in the process of conquering the Arsi Oromo. However, the Emperor made a crushing defeat through mutilating the right hand of men and the right breast women of Arsi Oromo. As a result, the Arsi people lastly forced to accept the monarchial system. Their socio-political institutions like 'Macca' and 'Tulama' deteriorated. Their culture and language were also undermined (Haji Abbas, 1995; Bichaka; 2004 Ezekiel, et. al, 2014).

After more than a century of the Anoole incident, Oromia Regional Government constructed Anoole Martyr's memorial monument which includes a museum by cost of 20 million birr for remembrance of Arsi Oromo people who lost their life and their body part during the imperial expansion of emperor Menelik II. Therefore, the mutilated hand holding mutilated breast monument depicts the act that its historical narratives centers on the imperial expansions of Emperor Menelik II in 1889 to Arsi Oromo people.

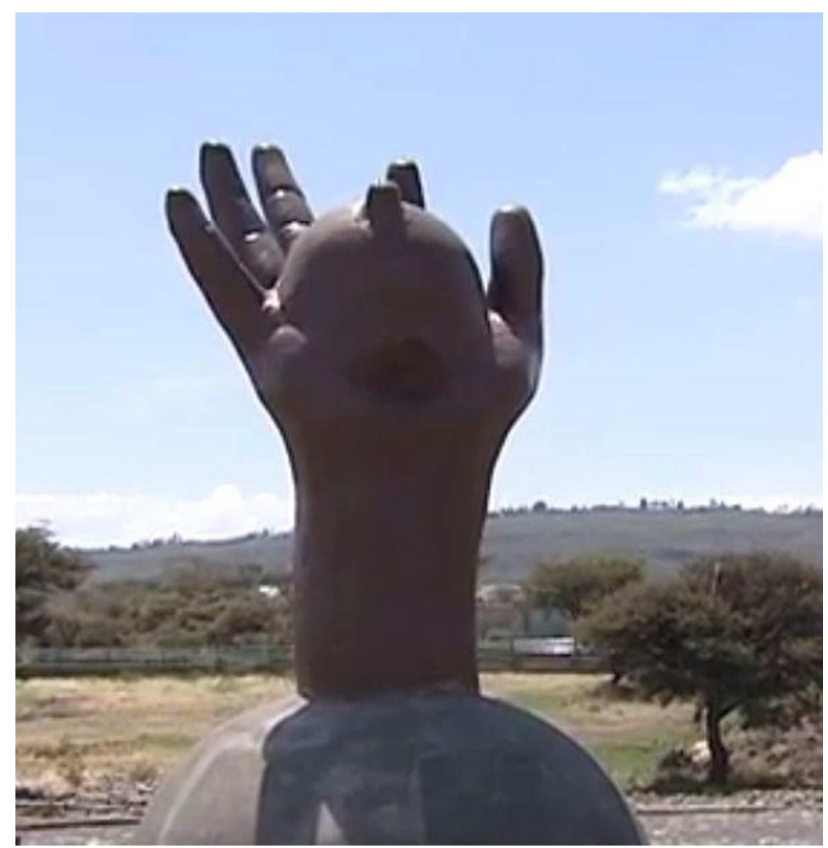

Figure 1. Anoole Memorial Monuments at Hexosa, Arsi. 


\section{Rationale}

The constructed statues in the period of FDRE (Federal Democratic Republic of Ethiopia) mainly focus on narratives of past political oppressions. The majority political narratives revolve on war made by EPRDF to overthrow the Derg, the socialist regime. However, the political narratives for construction of Anoole memorial monument focus on the horrific act happened on Arsi Oromo during the regime of imperial monarchy. Its construction is perceived and interpreted in polarized way by the two major ethnic groups in the country. [7], As Turton (2006), Ethiopians, mainly the two major ethnic groups (Amhara and Oromo) have contradictory view over the history of modern Ethiopia which begun from the imperial monarchy regime. On the one hand, many Ethiopians who benefited from the Monarchical system mainly from the Amhara ethnic group pride themselves over their country's effective resistance to colonialism and create an independent state hood during the imperial monarchy. On the contrary, many from Oromo ethnic group show antipathy towards the wars of imperial expansion and conquest. Hence, Anoole statue have become the space for controversy among the monument major ethnic group in Ethiopia. Despite the fact that there are ambivalent groups, several pro and counter-narratives were raised mainly from the major ethnic groups in Ethiopian polity. Therefore, this study discusses the theses and antitheses Anoole statue in the Ethiopian polity.

\section{Methodology}

This study aims at examining the pro and counter narratives of Anoole memorial monument in the Ethiopian polity. It focuses on the monuments historical narratives that related to power. The study uses informants from academic and political domain as primary data sources. Both Academic and political domains and, then, the participants from both the domains are selected through purposive sampling method. [8], As Cohen and et al (2005) notes, purposive sampling is one of the most common sampling strategies in which participants are selected depending on their importance to the objective of the study. Thus, six participants, three from Academics and three from political domains are selected to get first hand information due to they had an informed opinion on the narratives of Anoole monument. As secondary data source, official document from the Oromia Culture and Tourism Bureau Tourism (Jildii 1 ffaa, Bitotessa, 2006) and four currently closed down private magazines (Konjo, Addis Guday, Jano and Lomi) were purposively selected due to they give high coverage to the subject under investigation. The time frame is from Anoole Marty's monument inauguration (8 April 2014) up to the last publication of the selected magazines (5 August 2014). However, due to the repetitions of the story angle, the fresh angels of the stories were selected using convenience sampling method. To get the necessary information from both primarily and secondary source of data, in depth interview was conducted with informants and document analysis was used for documents as the main data gathering tools. The collected data through aforementioned tools are analyzed and discussed qualitatively.

\section{Discussion}

\subsection{Introduction}

The issues of Anoole memorial monument was the point of argument since its inauguration. The discord begun when the Ethiopian singer Tewdros Kassahun (Tedy Afro) song 'Menelik Tikur Sew' (Menelik the Black Man) in 2004 E. C which praise the emperor Menelik II deeds during the imperial monarchy. In addition, the singers' response on the interview held with Konjo magazine (December 2013, Volume 107) about the civil war during the reign of Menelik II as a [9], 'Holly War' upset many people from the victims group. As a result, a mass protest was held on social media and around 18,000 people signed petition in a day to boycott of Bedele Brewery the five million birr sponsor of the singer's concert in different parts of Ethiopia. Oromo Diasporas also highly condemned the singer adoration for the atrocious deeds of the emperor during the civil war. Different artists from the victims group like Kemer Yosuf also sung 'Menelik Bineensa' (Menelik the Butcher) as a response to Tedy Afros' song to denounces the reign of Menelik II in general. Moreover, the construction of Anoole monument in April, 2014 at Arsi, Hetosa aggravated the controversy over the reign of emperor Menelik II. The monument was constructed to commemorate the horrible death of Arsi Oromo during the emperor's civil war.

In this regard, various individuals from academic and political spheres have been argued in polarized way on the Anoole memorial monument historical narratives that related to power. Besides, different magazines were hyperactively reported the issue of Anoole monument. Mainly, the controversies were highly took place between the major ethnic groups, Oromoo and Amhara in Ethiopia due to these major ethnic groups saw the period of Emperor Menelik II, and the imperial Monarchy regime generally in polarized way. The Oromo people particularly the Arsi and Harar were traumatized and lived unpleasant life during the reign of Menelik II (1885-1914). On the contrary, the emperor's forebears predominantly from the Amhara ethnic group were the beneficiary of the monarchical system. As a result, the constructions of Anoole statue which depict the unpleasant act of emperor Menelik II become the point of controversy among most of people from the two major ethnic groups in Ethiopia. Under this section, the gathered data through indepth interview and document analysis are analyzed and presented.

\subsection{The Pro Narratives of Anoole Memorial Monument}

It is obvious that monuments are constructed for commemoration or memorial purposes. As USIP (United States Institute of Peace) (2007:2), [10], "Commemoration is 
a process that satisfies the desire to honor those who suffered or died during the conflict and as a means to examine the past and address contemporary issues". Similarly, Anoole statue was built in Oromia region, Arsi Hetosa by Oromia Regional Government for remembrance of Arsi Oromo people who lost their life and body part during the imperial expansion of emperor Menelik II. As Ato Muktar Kedir, the former president of the Oromia regional state and chairman of OPDO (Oromoo People Democratic Organization) said on the inaugural ceremony of the statue, [11], "The erection of this memorial monument is to commemorate those Oromoo heroes and heroines who were cruelly massacred for strongly resisting the oppressive regime." In fact, the period of imperial monarchy in Ethiopia oppresses several ethnic groups such as Sidama, Kafa, Wolaita, and others. These ethnic groups resisted the Nefxegna (Gun barer) system due to they have strong socio-political system. The Oromoo people, particularly, Arsi not simply became the serfdom for the system. It was difficult for the people detached from Gadaa, which is the backbone of their socio-political system that has governed them since their emergency. The Gadaa system is an example of traditional African form of democracy though it is lately registered by UNESCO in 2016. There are five generation groups and once in a system it took each forty (40) years to complete the cycle of eight periods of the calendar. At each stage, the members learn the Oromo history, military strategy and governance. [12], Keller, (1995) and Assefa (2010) also argued that Gadaa system is one of the Oromo administrative systems that all the Oromo people obeyed and governed for many years.

During emperor Menelik II fought to conquer the Arsi Oromoo, it was the period of Gadaa power transition. The power transition ceremony among Arsi people where took place at Anoole. As official document from Oromia Culture and Tourism Bureau (2006:2-3) shows [13], Anoole was the place where the Gadaa system is practiced. Unfortunately, when Menelik army crushed the resistant Arsi Oromo, it was the period of power transition of Gadaa system which took place every eight years. It was the period when Arsi 'Roobaale' power ended and transferred to 'Birmajii'. Menelik II and his soldiers then understood that they would not enslave the Arsi people if the Gadaa system exists.

Thus, Anoole was strategically chosen because it was a symbolic site of Arsi power and what is reverently referred as 'Arsooma', a custom by which the Arsi Oromo elected their leaders, made laws, deliberated on war and peace, and settled theirs inter and intra-clan disputes according to the Gadaa system. It is the superglue that held the Arsi tightly together. Menelik II and his soldiers couldn't simply abolish the system and make the Arsi people ruled under the Neftegna system. The Arsi Oromoo fought and defeated Menelik II military more than five times. As Haji Abbas (2014: 64-67) also stated that [14], Arsi engaged the Shewan in at least six battles between 1882 and 1886. Right from the start the Arsi were set up to engage in an unequal war since they did not possess firearms. Under these conditions, confronting the colonial force equipped with thousands of rifles, pistols, and some canon and advised by European instructors was difficult to undertake. Thanks to massive mobilization, solidarity and determination they not only successfully resisted but also inflicted causalities on Shewan soldiers... The Arsi continued to put up strong resistance including at 'Albaso' where they killed about 2000 Shewan soldiers in one night alone.

After many defeats of emperor Menelik II, his companions from Oromoo ethnic who already lost their identity and become Amarized (being Amara) like Ras Gobana Dace, Ras Darge, and Tuke Mama over week discussion decided to end the Gadaa system through traumatizing the people by mutilation and massacre. Stressing this, Ezekiel (2014:70) states: [15], With Ras Darghe, the emperor decided to conclude this horrible war in a blood bath. He invited the Arsi Oromo to Anoole, a strategic place was deliberately chosen for the odious crime he was contemplating, under the pretext of making peace. The unarmed Arsi were asked to pass through the entrance one by one. Those entered were not allowed to return and the Arsi men right hand was cut off and women's breast were removed... The act was done not only to avenging Shewan early loses but also to annihilate and demoralize the Arsi military for generation in order to make them totally submissive and subservient to Shewan colonialism.

The mutilation of hand and breast made the Oromoo lost their independence and transformed into landless 'Gabbars' (a sort of serfdom). The abolishment of Gadaa system which is highly tied with Oromummaa, being an Oromo created an identity crisis among the Arsi Oromoo. [16], As Baxter, Hultin and Triulzi (1996) also argue that the domination of Abyssinians over the indigenous Oromo people undermines the Oromo identity and suppressed the Oromo political and religious institutions. As a result, the Oromo people are assimilated to Abyssinians' culture, language and religion. Thus, Anoole statue depicts the strong resistance of Arsi people to keep their Gadaa system that connotes the scarification for freedom and independence. The construction of Anoole memorial monument, therefore, is seen as symbol of freedom and independence. It has symbolic resonance like the other monuments constructed in most Africa countries to symbolize their freedom and independence after European colonization. In addition, the unity of Arsi Oromoo and their strong resistance of the conquest have been taken as an exemplary hub in the process of current unification of Oromoo people.

What is more, Anoole memorial monument has been perceived as an emblem and outcome of the contemporary Ethiopia political system (ethno-linguistics based federalism). As Larsen (2013:5) states that [17], "Since democracy does not function through command or coercion, requires instead a constant renewal of sets of symbols symbols which appeal to people and instill in them a sense of belonging and identification." Thus, the construction of Anoole statue in the Oromia region is taken as the outcomes of democracy and the federal structure.

The conquest of Menelik II not only abolishes the Arsi 
Oromo's socio-political system (Gadaa) but also confiscate their economic resources. As official document from Oromia Culture and Tourism Bureau (2006: 3) shows, [18], "Menelik II and his soldiers exploited the Arsi Oromo's natural resources, took a large number of cattle and make them slave labor on their own land." In addition, Alamayo (1901:349) also argues, [19], "During the protracted war of conquest and the pacification that lasted for several decades, vast amounts of property belonging to the conquered people was confiscated or destroyed, and millions of head of livestock were looted." Hence, the Arsi people became economically weak and dependent on the Abyssinians who already controlled their resource. As a result, the Arsi people became 'Gebbar' (serfdom) under the 'Neftegna' system.

Furthermore, the mutilation of hand of men and breast of women create psychological trauma among the Arsi People. As informant from OPDO (personal interview, 3 April 2015) said [20], "Due to Arsi people resist the Menelik II conquest, the breast of women and hands of men were mutilated. The act was happened not because killing was difficult, but it is needed to traumatize the people never protest against the regime". Thus, the design of Anoole monument, mutilated hand holding mutilated breast is replica of the act happened on Arsi Oromoo during the reign of Menelik II. As the official document from Oromia Culture and Tourism Bureau (Volume One, March 2006:2) also shows [21], The act of hand and breast mutilation happened at the end of war in 1886. Ras Darge and Menelik's army ordered those in attendance at the "peace" gathering to enter a narrow pass one by one. Then, the right hands of all men and the right breasts of the women were cut off. The mutilated hand and breast also tied to the neck of the victims. This act happened to frighten the Arsi people who defeated Menelik II army for several time.

The Anoole mutilation, 'Harkaaf Harma Muraa Anoole', as it is widely known, negatively affected the Arsis' sense of being human at the time. It remains seared indelibly in their collective memory. Haji Abbas (1995: 4) also state that [22], "after the failure of four campaigns led by Menelik in person, the Shoan [Shewan] army was far from victorious so they introduced a systematic mutilation of the right hands of men and the right breast of women to terrify the Arsi and force them to abandon their hostility." The mutilation of right hand and right breast was a well-thought strategy to traumatize the people. The reason why right hand and right breast mutilation is not because of denotatively the men are right handed and the women breast fed their children by their right breast. Connotatively, 'Right' shows the good moral, ethics, and being the owner of the land and the right of people using their resource without any external order and control. Thus, Anoole statues is constructed to harness memory of victims and to learn lessons from the past act in an effort to avoid repeating it in the future.

\subsection{The Counter Narratives of Anoole Memorial Monument}

The construction of Anoole monument is not collectively accepted by all people in Ethiopia. Several counter-narratives have emerged on its construction due to the historical base of the statue emphasize on the negative side of the civil war during the reign of emperor Menelik II. [23], However, emperor Menelik II contributed a lot for current Ethiopia. First, he played a great role for the formation of modern Ethiopia. The emperor made several campaigns to different parts of the country to build a nation. He took both peaceful and forceful measures in order to different independent landlords subjugate their power. For instance, Abba Jifar of Jimma, Kumsa Moroda of Wellega and others peacefully subjugated their power while Kawo Tona of Wolita and the Abba Gadaa of Arsi and Harar Oromoo subjugated their power under coercion. Participant from History department (Personal interview, 09 April 2015) also said [25], The first phase of Menelik expansion was the most hostile expansion. For instance, the conquest of Gibe, Harar area, Arsi, and Bale were bad. The Oromo people around that area whether organized or unorganized, Oromo's with state or without the state, with no doubt they resisted the expansion.

In the process of building one nation, the campaign of Menelik II is seen as a process of reunification (not exploration) of the people who were an offshoot of Christian kingdom and recovery of territories that were once part of the Abyssinians. As Participant from History department (Personal interview, 09 April 2015) said [26], When Menelik II conquered several areas during his reign, he was contemplating and then most of his nobilities were thinking as they were conquering the land which belongs to them before $16^{\text {th }} \mathrm{C}$. Therefore, Arsi, the highland areas of Bale and Harar were tributary of Christian kingdom before $16^{\text {th }} \mathrm{C}$.

From the terminology, the campaign of Menelik II to Arsi is seen as 'expansion' or reunification not 'civil war' or 'conquest'. Stressing this, [27], Tekletsadik (1983) and Bahiru (1991) argue that few letters emperor Menelik II sent to Europeans showed the emperor ambition to reestablish the ancient boundary of Ethiopian starting from Khartoum including all Oromo highlands up to the limits of the Somali, Ogaden. Therefore, the civil war among the emperor Menelik II and different independent states is seen as the process of reunification than internal colonization.

Besides, emperor Menelik II was the first person who introduced modern technologies in Ethiopia. In fact, [28], as Kebede (1939) and Tekletsadik (1983) stated different communication technologies like telephone, telegraph, and postal service, and infrastructures such as electricity, railway, hospital, school and bank were constructed in Ethiopia during the reign of Menelik II. Hence, emperor Menelik II is claimed as the father of modernization in the Ethiopian history.

Mentioning the crucial deeds of emperor Menelik II in the modern Ethiopia history, the historical base for the construction of Anoole statue which deconstruct the taken for granted narratives of the reign of Menelik II is taken as unauthentic history. As participant from political sphere, AEUP (All Ethiopian Union Party) (personal interview, 12 April 2015) said, [29], "Except showing the Anoole war was 
atrocious, there is no evidence that substantiate the mutilation of hand and breast. It is a fictitious oral history." Stressing this, Jano magazine (April, 2006. Vol. 2, No. 29) [30], criticized the construction of Anoole memorial monument and reported the history of hand and breast mutilation of Anoole as fake history produced to denounce the contributions of Menelik II for the current Ethiopian society. Thus, Anoole statue is seen as popular history created along with the introduction of ethnic politics in the modern Ethiopian history.

Moreover, Anoole monument has identity representation fallacy. As participants from Political Science department (personal interview 07 April, 2015) stated that the [31], statue wrongly portrays the Amhara ethnic group due to Menelik II is claimed to be from typical Amhara ethnic group. However, all historical accounts showed Shewa was a multiethnic region with a significant Oromo population. Even during the civil war, the emperor Menelik militaries were lead by Oromoo Generals. [32], For instance, Gobana Dache was the chief commander of Menelik II who took the forefront in the massacre of Oromo people. As Abbas Haji (1995) also argued that [33], the conquest of emperor Menelik II was not done only by his shewan Amhara, but it was carried out also by divided Oromoo among themselves. Hence, Oromoo that massacred other Oromoos' and Anoole statue purportedly shows hatred out of clearly witnessed the historical facts.

Furthermore, the design of Anoole monument is highly criticized. Participant from Blue Party (Personal interview, 15 April 2015) argued that [34], the architecture of Anoole has psychological and moral impact on the community around the statue and between the major ethnic groups in Ethiopia. The direct representation of the statue reminds the people negative historic incident. Stressing this, informant from Fine Art department (personal interview 10 April 2015) explains [35], Artistically, when histories are depicted through statues/monuments, artists should transform, not translate the history like photographic form. In this case, Anoole statue is a failure due to it is one to one representation and translation of horrific history. It lacks the artistic transformation into an everlasting visible object.

Thus, Anoole memorial monument is not architecturally standard. It lacks an artistic quality. In the process of commemorating an atrocious history through the statue, the history must be transformed to add an artistic quality not to disturb the peoples' feeling. The statues' lack of aesthetic value has a psychological impact for generations to come. For instance, [36], the holocaust memorial monuments constructed in several Europe countries through artistically transformed manner. The design of holocaust monuments did not directly reflect the horrible massacre of Jews people during the Second World War.

The informant from Blue party (Personal interview, 15 April 2015) also argues that the [37], statue inculcates hatred and vengeance rather than preaching forgiveness, tolerance, and peaceful coexistence among the society. The statue is the symbol of lost and defeated history even for the people whom the statue was erected for. It instills a looser mentality as a result the coming generation lacks confidence, trust and always wants to avenge. Different nongovernmental magazines also criticize the architecture of Anoole monument. As Addis Guday, (April 2006, Volume 8, No. 124 , p. 14) [38], Rather than forecasting the bright future of the Oromia and symbolizing forgiveness, transparency and unity, Anoole is a disgusting statue which flashback the past awful history and epitomizes hate and poison in the mind of generations to come to avenge over the past deed (translated).

Stressing this, Lomi magazine (April 2006, Volume, 102, p. 12) also states, [39], the design of mutilated hand holding mutilated breast have no any positive impact but rather it has a psychological impact particularly for the children who grow up around the statue (translated).

\section{Conclusion}

Anoole memorial monument is erected to commemorate the gallant Arsi Oromo fighters whose right hand and right breast were amputated during the imperial expansion in the reign of Emperor Menelik II. Beyond its commemorative site, the thesis of Anoole statue first and foremost emphasize on strong resistance of Arsi Oromoo. In this, the monument epitomizes the strong administrative structure, great sense patriotism and the unity of Arsi Oromoo under Gadaa system to resist the imperial yoke. Thus, Anoole memorial monument is the symbol of freedom, independence and equality of Arsi people and Oromoo in general to protect their indigenous culture, religion, socio-political system and language which are in short the identity of Oromoo, Oromumma. However, these thesis are counter narrated by the statues' historical fallacy symbolizes and its design that is not crafted in a civilized way to create an everlasting memory and at the same time to be the source of peace and reconciliation. The statues' design lacks thorough examination on its impact from both perpetrators and victim's side.

\section{References}

[1] Aalen L. (2002). Ethnic Federalism in a Dominant Party State: The Ethiopian Experience 1991-2000. Norway. Chr. Michelson Institute Development Studies and Human Rights.

[2] Alamayo Kano. (1901). The Oromo: An Ancient People in the State of Menelik. Finfinnee. Oromia Culture and Tourism Bureau.

[3] Armstrong P and Choudhury B. (2006). Monument and Architecture in Shaping Bangladeshi National Identity. University of Sydney. Faculty of Architecture.

[4] Asafa Jallata. (2010). Celebrating Oromo Heroism and Commemorating the Oromo Marytrs' Day (Guyya Gootota Oromiyaa). Sociology Publications and Other Works. University of Tennessee, Knoxville. Retrieved on 12 March 2014 from http://trace.tennessee.edu/utk_socopubs/12 
[5] Assefa Fissiha. (2006). Theory Versus Practice in the Implementation Ethiopia's Ethnic Federalism. In Turton, D (ED), Ethnic Federalism: The Ethiopian Experience in Comparative Perspectives (pp 131-162). Oxford. James Currey.

[6] Bahru Zawde. (1991). A History of Modern Ethiopia, 18551974. London. James Currey.

[7] Baxter P. T. W, Hultin J. and Triulzi A. (1996). Being and Becoming OROMO: Historical and Anthropological Enquiries. USA. The Red Sea press, Inc.

[8] Bichaka Fayisa. (2004). The Journal of Oromo Studies. USA. Middle Tennessee State University.

[9] Cohen L, Manion L and Morrison K. (2005). Research Method in Education ( $5^{\text {th }}$ ed). New York. Rutledge Falmer.

[10] Doresse, J. (1959). The Greatness of Ethiopia: Legends \& Reality. In UNESCO report October, 1959, Africa's Lost Past: The Startling Rediscovery of a Content (pp 30-32). France: UNESCO.

[11] Ezekiel Gabissa. (2014). Contested Terrain: The Oromo and Ethiopian Studies. USA. Lutheran University Press.

[12] Finneran N. (2012). Lucy to Lalibela: Heritage and Identity in Ethiopia in the Twenty-First Century. International Journal of Heritage Studies, 19:1, 41-61. Retrieved on 15 May 2014 from http://dx.doi.org/10.1080/13527258.2011.633540

[13] Forest and Johnson. (2010). The Politics of Public Space: What Can Political Science Contribute to the Study of Monuments? Paper presented at Canadian Political Science Association; Montreal.

[14] Haji Abbas Ganamo. (1995). Menelik's Conquest as the Genesis of Ethiopian Crises. A case of the Arsi Oromo. The Oromo Commentary.
[15] Hashim Tewfik. (2010). Transition to Federalism: The Ethiopian Experience. Ottawa, Ontario. Forum of Federations.

[16] Kebede Tesema (1939). The Note of History. Addis Ababa.

[17] Keller J E. (1995). The Ethnogenesis of the Oromo Nation and Its Implications for Politics in Ethiopia. Journal of modern African studies, 33, 4, pp 621 - 634. Cambridge University press.

[18] Larsen L. (2013). Power, Politics and Public Monuments in Nairobi, Kenya. Retrieved on July 10, 2014 from http://www.opendemocracy.net

[19] Marcus H. (1994). A History of Ethiopia. Berkeley: University of California Press.

[20] Mekuria Bulcha. (1996). The Survival and Reconstruction of Oromo National Identity. In Being and Becoming OROMO: Historical and Anthropological Enquiries. (Ed.) by Baxter P. T. W, Hultin J. and Triulzi A. (1996). USA. The Red Sea press, Inc.

[21] Merera Gudina. (2003). Ethiopia: Competing Ethnic Nationalisms and the Quest for Democracy, 1960-2000. Addis Ababa. Chamber Printing House.

[22] Oromia Culture and Tourism Bureau. (2006). Culture and Tourism. $1^{\text {st }}$ Ed. Finfinne.

[23] Tekletsadik Mekuria. (1951). The History of Ethiopia from Nubia- Aksum, Zagwue to the Atse Yiknoamilak Dynasty. Tinsea Printing Press. Addis Ababa.

[24] USIP. (2007). The Urge to Remember the Role of Memorials in Social Reconstruction and Transitional Justice. Stabilization and Reconstruction Series No. 5. Washington, DC. Retrieved on 8 April 2014 from www.usip.org 